Barbara TURK NISKAČ

Simona KLAUS

Saša STAREC

\title{
Urbano življenje ob kmetijah ali ruralno življenje ob stolpnicah? Dilema jasne ločnice med urbanim in ruralnim
}

V prispevku se na primeru Ljubljane obravnava odnos med mestom in podeželjem, med urbanim in ruralnim. $S$ pogovori s prebivalci četrtne skupnosti Posavje smo poskušale ugotoviti, kako posamezniki glede na svojo interakcijo, prakse in odnose $\mathrm{v}$ širšem prostoru bivanja oblikujejo ločnice med ruralnim in urbanim ter kam jih umeščajo. Obravnavano območje razumemo kot vmesni prostor, v katerem prihaja do prehajanja med podeželjem oziroma ruralnim prostorom, katerega najopaznejši znak so bližnje njive in kmetije, in mestom kot urbanim prostorom, ki ga najbolj določa infrastruktura, vezana na urban način življenja. V raziskavi se je pokazalo, da se pogledi prebivalcev blokovskega naselja BS 7 precej razlikujejo od pogledov prebivalcev Savelj, Ježice, Kleč, Male vasi in Stožic. Dojemanje prostora je povezano tudi s starostjo. Različne osebne izkušnje in različni interesi posameznikov vplivajo na njihove vrednostne sisteme, prek katerih doživljajo prostor.

Ključne besede: urbana antropologija, urbano, ruralno, Ljubljana, Slovenija 


\section{Uvod}

Kaj je mesto, kaj so njegove značilnosti, kako ga raziskovati in razumeti, kaj početi z mestom - ta vprašanja se intenzivno zastavljajo vse od konca 19. stoletja. Z mestom se na eni strani ukvarja urbanizem, tj. znanost, ki načrtuje mesta, na drugi strani pa urbana sociologija in urbana antropologija, ki si prizadevata razumeti mesto prek življenja njegovih prebivalcev. Mesto nas torej lahko zanima tako po svoji fizični (videz) kot po svoji družbeni plati (ljudje). Osnovna binarna opozicija, ki pogosto sproži razmišljanje o tem, kaj je mesto in kaj ni, je opozicija mesto-podeželje oziroma urbano-ruralno. $\mathrm{V}$ raziskavi smo se posvetile prav tej opoziciji; ogledale smo si jo prek vprašanja, kako ljudje zaznavajo prostor, $v$ katerem se prepletajo fizični elementi mesta in podežlja, urbanega in ruralnega. Kakšna je narava te opozicije, ali obstaja ločnica med prostoroma, kakšna je in zakaj obstaja, če obstaja? Odgovore na zastavljena vprašanja smo poskušale najti na podlagi študije primera Ljubljane.

Če pogledamo zemljevid Ljubljane, ima mesto obliko zvezde, ki se s kraki razprostira po prostoru. Ti kraki so se izoblikovali ob glavnih prometnih vpadnicah, ki povezujejo središče mesta $z$ njegovim zaledjem in drugimi mesti. Z razvojem in s širjenjem mesta je prihajalo do spajanja mesta $\mathrm{z}$ vaškimi naselji ob glavnih vpadnicah v mesto. Posledica takšnega razvoja mesta je današnja podoba Ljubljane, ki na obrobnih predelih med vpadnicami še ohranja elemente vaškega prostora. V kolikšni meri je ohranjena prvotna, vaška podoba prostora, to je fizično, v arhitekturi, ali v praksi, kot delujoče kmetije, je odvisno predvsem od bližine vpadnic, okoli katerih se je Ljubljana urbanistično širila.

Eno takšnih območij prehajanja mestnega v vaško okolje ter mejnosti med mestom in podeželjem je tudi širše območje četrtne skupnosti Posavje, ki se nahaja med severno mestno obvoznico in Savo ter je od središča Ljubljane oddaljeno približno 5 kilometrov (slika 1). Za to območje je po eni strani značilna stanovanjska soseska BS $7 \mathrm{z}$ visoko blokovno gradnjo in gosto naseljenostjo, po drugi strani pa stanovanjsko sosesko obdajajo nekdanja vaška naselja Ježica, Stožice, Mala vas, Savlje in Kleče (slika 2). Ta so v določeni meri ohranila vaški značaj obcestne poselitve, marsikje pa se še ukvarjajo s kmetijstvom - najbolj v Klečah, ki so od vpadnice najbolj oddaljene, poleg tega pa tudi v Stožicah in starem delu Savelj.

Takšna narava ljubljanskega obrobja ga vzpostavlja kot mejno območje, na katerem se mešajo značilnosti ruralnega in urbanega. $S$ tem pa se pojavlja vprašanje, ali je ločnica med podeželjem in mestom, med ruralnim in urbanim, res tako jasna in določena? Kakšna je njena narava? V naši raziskavi nas je

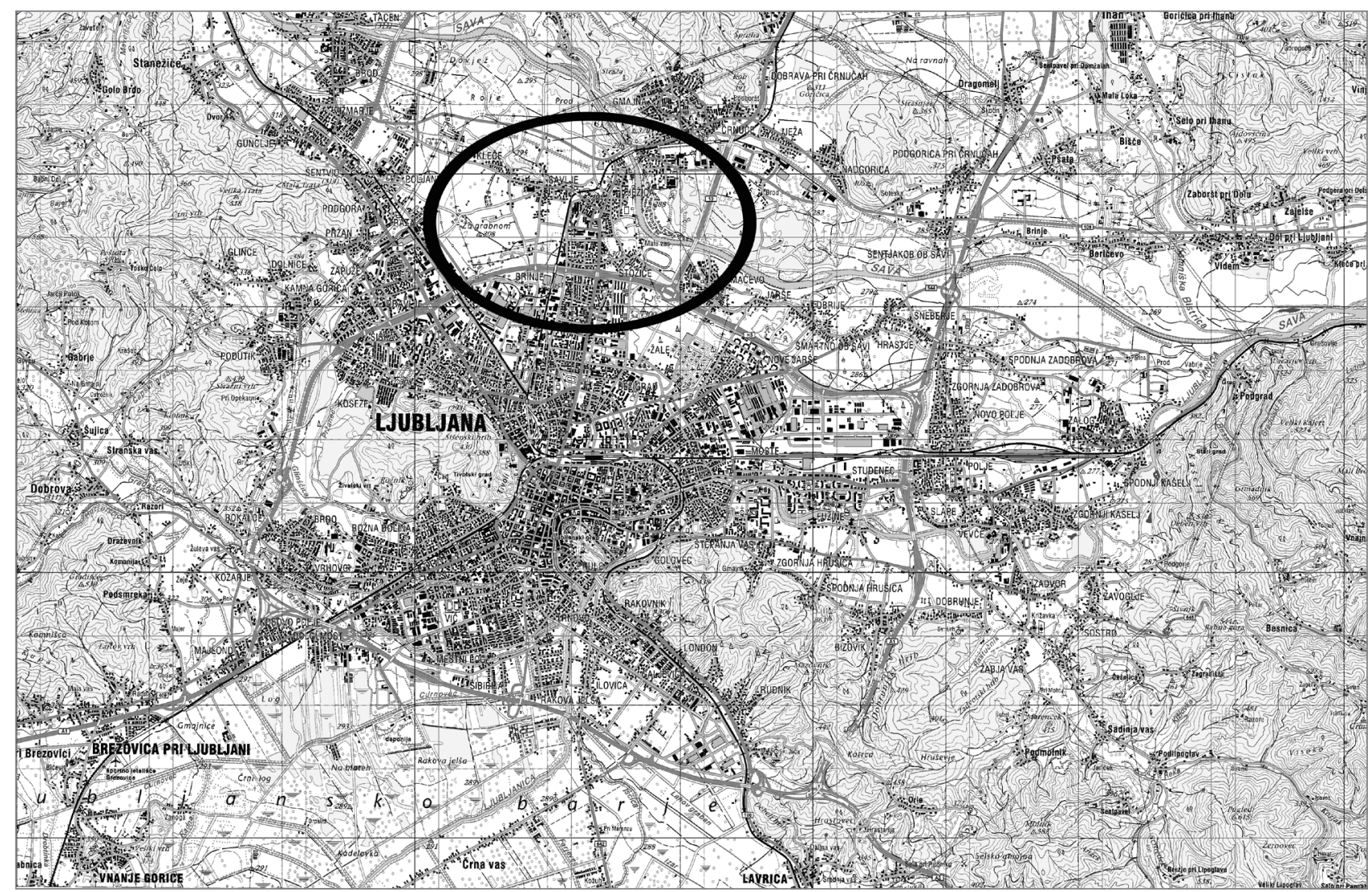

Slika 1: S krogom je na zemljevidu Mestne občine Ljubljana prikazano območje preučevanja, to je širše območje četrtne skupnosti Posavje (vir: Geodetska uprava Republike Slovenije, 2010). 


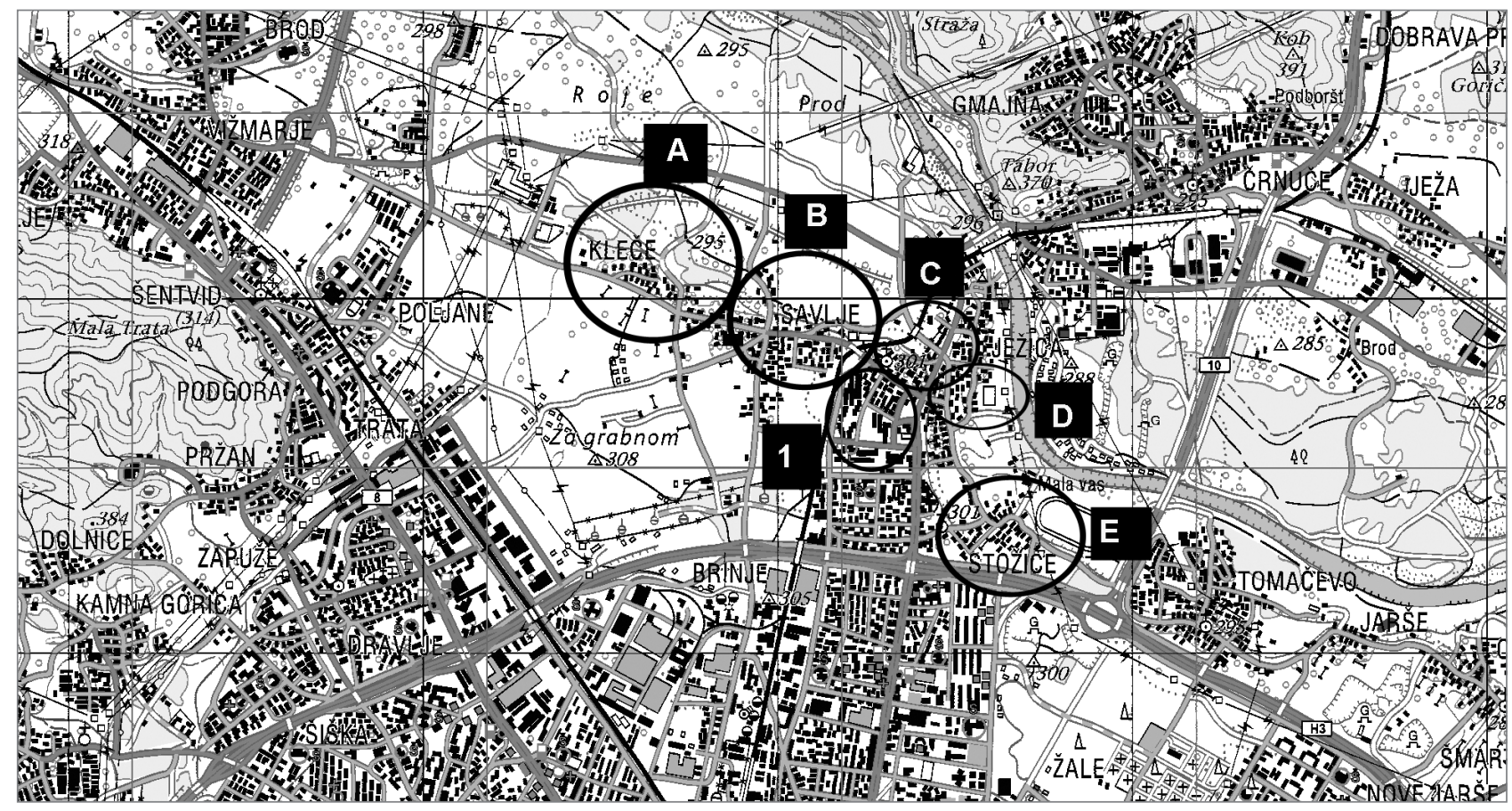

Slika 2: Stanovanjska soseska BS 7 (1), Kleče (A), Savlje (B), Ježica (C), Mala vas (D), Stožice (E) (vir: Geodetska uprava Republike

Slovenije, 2010)

zato zanimalo, kje poteka ločnica med podeželjem in mestom na območju četrtne skupnosti Posavje ter kako posamezniki glede na svojo interakcijo, prakse in odnose v tem prostoru in do njega oblikujejo te ločnice. Zanimalo nas je, kako ljudje na tem območju konstruirajo ločnice med ruralnim in urbanim ter kam jih umeščajo.

Terensko delo v četrtni skupnosti Posavje je potekalo med junijem in avgustom 2009. Opravile smo več polstrukturiranih intervjujev z naključnimi mimoidočimi. Za raziskavo smo izbrale popolnoma naključen vzorec anonimnih sogovornikov. $\mathrm{V}$ pogovor je privolilo 29 ljudi, od tega 13 moških in 16 žensk. Starost sogovornikov je bila med 15 in 75 let, prevladovali so nekoliko starejši sogovorniki, in sicer od 55 do 75 let. Najprej smo sogovornike poiskale na območju BS 7, na javnih površinah bližnjega parka in med bloki. Nekateri v BS 7 živijo že več let, drugi so se tja priselili pred kratkim ali pa tam bivajo le začasno. Kot protiutež sogovornikom, ki živijo v BS 7, smo poiskale sogovornike z območja Savelj, Kleč, Ježice in Stožic, saj smo predvidevale, da bodo njihove interpretacije prostora na tem območju nekoliko drugačne od tistih, ki smo jih zabeležile med prebivalci BS 7.

\section{Teoretično izhodišče}

Odkar se je znanost začela ukvarjati z vprašanjem, kaj je mesto in kaj ga določa, so se zvrstile različne definicije mest, različni kriteriji, ki naj bi določali mesto in po katerih naj bi mesto tudi prepoznali. To pa ni tako preprosto, saj lahko pogledamo na to vprašanje z več vidikov. Urbana semiotika se pri interpre- taciji opira predvsem na fizične (vidne) označevalce prostora, kot so njegova narava, zgradbe in dogodki. Obstajajo zunanje značilnosti prostora, na podlagi katerih ljudje neki prostor povezujejo ali s podeželjem ali z mestom. Mesto se največkrat povezuje s stolpnicami, hrupom, prometom, z neobstojem narave, mestnim avtobusom, javnimi ustanovami in s cestami. Alister Scott idr. (2007) kot glavne značilnosti urbanega navajajo obseg pozidanega območja, gostoto prebivalstva, načrtovanje funkcionalnega območja mesta, ki poleg pozidanega območja zaobjema tudi naselja na podeželju, ter neosebne in anonimne odnose med prebivalci. Podeželje je nasprotno prostor narave, miru, odmaknjenosti od glavnih cest, območje kmetij in kmetijskih površin. Po mnenju istih avtorjev so za ruralna območja značilni bolj osebni in intimnejši družbeni odnosi. Po njihovem mnenju lahko ruralno definiramo tudi kot neurbano, zanj so značilni redka poseljenost, obsežna raba zemlje, primarne ekonomske aktivnosti in zaposlitve. Na podlagi teh označevalcev prostora bi lahko jasno mejo med mestom in podeželjem potegnili glede na obstoj oziroma koncentracijo teh označevalcev v prostoru. Vendar opredelitev z označevalci ni tako jasna in ni dvoumna, kot bi si želeli. Zapletemo se lahko že pri konceptu urbanega in ruralnega. »Koncept ruralnega je večplasten. Ena od težav je raznolikost ruralnih območij, ki lahko variirajo od majhnih naselij na obrobjih velikih mest do odmaknjenih vasi /.../ Druga težava so ekonomske in družbene spremembe v ruralnih območjih, ki oblikujejo medsebojne odnose z urbanimi območji in kulturami.« (Scott idr., 2007: 4.) To še posebej velja za mejna območja, na katerih se ti zunanji označevalci med seboj prepletajo. 
Drugi teoretski vidik se navezuje na osebne interpretacije okolja in prostora, v katerega so vpeti posamezniki. »Različni ljudje interpretirajo svoja okolja različno, glede na svoje ozadje in izkušnje. Ne obstaja eno samo okolje - okolje je mentalna konstrukcija.« (Madanipour, 1996: 63.) Zavedati se moramo tudi, da je »človeško bivanje vedno zgodovinsko in prostorsko pogojeno « (Bender, 2001: 3). Prostor in čas določata ljudi v sebi. Hkrati pa prisotnost posameznikov v prostoru določa njegovo naravo. Ti procesi niso statični, ampak so vedno $\mathrm{v}$ gibanju (Ardener, 1997; Bender, 2001). Kot piše Rajko Muršič (2006: 51), dajemo, če razmišljamo o prostoru, »prednost procesu njegove družbene konstrukcije, dejavnemu prostorjenju /.../, ne pa samemu prostoru in njegovim konkretizacijam ([po]krajina, območje, kraj, mesto, nahajališče, lokacija «. Pri raziskovanju in razumevanju mesta se lahko zato zatečemo tudi k praksam vsakodnevnega življenja, ki jih ljudje izvajajo in $s$ katerimi ustvarjajo prostor kot urbani/mestni ali ruralni/podeželski. Marvin Harris je v etnološki raziskavi brazilskega mesta pokazal, da se ideja mesta skriva $\mathrm{v}$ ljudeh in njihovem načinu življenja, v njihovih vsakodnevnih praksah, mentalnih mapah in $s$ tem $\mathrm{v}$ vrednotenju prostora. »Mesto je tukaj, čeprav ni jekla in betona, « piše Harris (1956: 11). Mesto se je Harrisu razodevalo skozi odnos ljudi do prostora, v praksah ljudi, ki so ustvarjale urbani etos prostora. Tisto, kar je bilo Harrisu pomembno pri razumevanju opozicije mesto/podeželje, je, da se je prebivalcem mesta zdelo, da so drugačni od ljudi na podeželju, ne pa število prebivalcev, gostota ali drugi zunanji znaki. Ideja urbanosti prostora se po njegovem mnenju ne skriva $\mathrm{v}$ videzu, temveč v percepciji ljudi; idejo urbanega gradijo predstave, ki imajo pomen v oblikovanju vsakodnevnega življenja ljudi. Zaznava in odnos do prostora izhajata iz načina življenja oziroma praks ljudi (kako upravljajo s prostorom, kako ga uporabljajo in konstruirajo z vsakodnevnimi praksami) ter njihove interpretacije fizičnega okolja, ki temelji na njihovih vrednotah in predstavah o tem, kaj je mesto in kaj podeželje, kaj urbano in kaj ruralno. Setha Low (1999) uporablja za takšno razumevanje prostora koncept družbene konstrukcije prostora, ki izhaja iz fenomenološke in simbolne izkušnje prostora. Ker nas urbana semiotika s spoznavnim aparatom, ki temelji na označevalcih, pri interpretaciji obravnavanega območja, pri kateri prihaja do mešanja ruralnih in urbanih elementov, spravlja $\mathrm{v}$ zadrego, smo se v tej raziskavi posvetile osvetlitvi tega, kam ljudje, ki bivajo na obrobju mesta, postavljajo mejo med mestom in podeželjem.

\section{Zgodovinski in prostorski kontekst širšega proučevanega območja}

Prve omembe naselij na območju, za katero se je uveljavilo poimenovanje Posavje in ki danes tvori istoimensko četrtno skupnost, segajo v srednji vek. Vas Savlje je bila prvič omenjena leta 1282, vas Kleče leta 1359, vasi Stožice in Ježica pa leta 1363. Leta 1850 so omenjene vasi skupaj $z$ vasema Tomačevo in Jarše tvorile občino Ježica ki je bila v tridesetih letih 20. stoletja priključena mestni občini Ljubljani (nastanek Velike Ljubljane). Lega ob mestnih vpadnicah in bližina mesta sta povzročili razvoj kmetijstva, ki je bilo usmerjeno predvsem $\mathrm{v}$ prodajo kmetijskih pridelkov v mesto. Zato sta bili v teh vaseh pomembni živinoreja, ki je mesto oskrbovala z mlekom, ter prodaja vrtnin v mestu. Proti koncu 19. stoletja je to območje, zlasti Ježica, postalo tudi priljubljena izletniška točka Ljubljančanov. Bližina mesta je posavskim vasem omogočala stalno interakcijo z mestom, zato je to območje že pred prvo svetovno vojno zajelo postopno spreminjanje ruralnega značaja vasi. Urbanizacija območja se je začela najprej v vaseh ob vpadnici (Mala vas, Stožice in Ježica), najintenzivnejša pa je bila po drugi svetovni vojni. $Z$ večjo navezanostjo na mesto se je postopno začela spreminjati tudi poklicna sestava prebivalstva. V letih med vojnama so postajali na kmečkih območjih pogostejši nekmečki poklici; največ je bilo delavcev, nato obrtnikov, trgovcev, gostilničarjev. Kmečke družine z večjim številom otrok so izplačevale dediščino v denarju ali s parcelo za graditev hiše in tako so začele nastajati prve delavske hiše z vrtovi. Pred prvo svetovno vojno so bile prve take hiše zgrajene v Stožicah, Mali vasi in na Ježici ob Dunajski cesti (Pajsar in Židov, 1991).

Čas po drugi svetovni vojni je zaznamovala pospešena urbanizacija območja in velik prirastek prebivalstva. Prva faza urbanizacije je bila osredinjena na Dunajsko cesto. Z njo je prišlo do spajanja obsavskih vasi z mestom, ki se je širilo z gradnjo individualnih hiš in stanovanjskih sosesk. Vaška naselja, ki so bila odmaknjena od glavne mestne vpadnice, so se zato urbanizirala manj intenzivno oziroma počasneje. To velja za Kleče, deloma za Stožice in stari del Savelj, najbolj izrazito pa sta se spremenili Ježica in Mala vas, v katerih so nastale individualne hiše z vrtovi. Leta 1961 so urbanisti v raziskavi Vplivno območje Ljubljane zapisali, da predeli ob vpadnicah kažejo jasne znake urbanizacije in s tem brezpogojne vključitve v Ljubljano (Okrajni zavod za Urbanizem Ljubljana, 1961). Kot so še zapisali v raziskavi, imajo naselja, ki potekajo med vpadnicami in vzporedno z njimi (gre za naselja ob Savi v smeri Kleče-Zadobrova) drugačen značaj od urbaniziranih površin ob vpadnicah. Ta naselja so »/.../ kljub temu, da leže nedaleč od Ljubljane, v veliki meri ohranila nekdanji kmečki značaj, urbanizacija je šla mimo njih. Po zunanjem videzu ne ustvarjajo videz naselja z mestnim značajem. Po vojni pa so se tudi tu spremenile strukture prebivalstva. To območje je priključeno mestu, ker delovna sila gravitira v industrijska področja, agrarna panoga pa je izgubila pomen« (prav tam: 25).

Obsavska naselja so bila tako v šestdesetih letih še vedno razumljena kot samostojna naselja in ne kot del mesta Ljubljane, 
čeprav so ji bila upravno priključena. Glavni razlog te percepcije, da ne gre za mestni prostor, izhaja iz zunanje podobe teh naselij. Glavni kriterij za to, da so bila ta naselja vključena v Ljubljano kot upravno enoto, je bilo to, da so prebivalci zaradi zaposlitve gravitirali proti mestu. $\mathrm{Za}$ obdobje po drugi svetovni vojni sta značilna prevladovanje urbanih poklicev in izrazit padec deleža kmetov, ki se zaposlijo v mestu. Kolikor je še bilo kmečkega prebivalstva, je šlo predvsem za polkmete, ki so se zaposlili v različnih poklicih v mestu (Pajsar in Židov, 1991). Velik udarec za kmetovanje na tem območju je pomenil tudi odvzem zemlje za potrebe gradnje stanovanj, ki jih je mesto potrebovalo ob naraščanju števila prebivalcev. Največji načrtovani urbanistični poseg $\mathrm{v}$ ta prostor je bila stanovanjska soseska BS 7, ki je bila med koncem šestdesetih let in osemdesetimi leti v več fazah zgrajena na območju kmetijskih površin okoliških kmetov.

Breda Mihelič (1983: 51) je o BS 7 zapisala, da »s svojimi visokimi objekti simbolično ponazarja najbolj severno mejo mestnega območja v mestni silhueti «. Koncept soseske, ki postane temeljni »element organizacije mestne površine « (Mušič, 1960: 4), se je v jugoslovanskem in s tem tudi ljubljanskem urbanizmu (in arhitekturi) uveljavil v šestdesetih letih. Načrtna, urbanistično zasnovana gradnja, ki jo ponazarja soseska, je pomenila nasprotje individualne in zasebne gradnje. Po Vladimirju B. Mušiču (1960) je bila ena temeljnih idej oblikovanja soseske, da naj bi ta spodbujala in omogočila razvoj osebnih in družbenih odnosov med prebivalci mesta, za katero naj bi bil značilen individualizem. Zasebna gradnja hiš naj bi individualizem mesta le še stopnjevala, zato naj bi stanovanjska soseska s svojo zasnovo poskrbela tudi za to, da se $\mathrm{v}$ mestni prostor prenese občutek medsebojne povezanosti, ki ga zagotavlja vaško okolje. Območje soseske naj bi omogočilo izoblikovanje stanovanjske skupnosti, ki so jo tedanji urbanisti opredelili kot »družbeno-ekonomsko kategorijo na polju notranje ureditve mestnega prostora « (prav tam: 4). Nanjo so gledali kot na »samoupravno enoto, ki naj pospešuje razvoj soseske « (prav tam). Gradnja sosesk je bila zato načrtna in premišljena, potekala je ob nadzoru urbanistov in arhitektov, katerih cilj je bil zasnovati urbani prostor, ki bo ljudem na območju soseske omogočil zadovoljevanje vseh pomembnih funkcij. Kot še navaja Mušič, je bilo pri načrtovanju sosesk najpomembnejše vodilo, naj se čim bolj upošteva potrebe ljudi. Zasnova soseske naj bi zato temeljila na premisleku o petih elementih, in sicer: stanovanjih, javnih zgradbah (šolah, družbenih in kulturnih organizacijah, trgovinah ...), reguliranju prometa (ulice, postaje, parkirni prostori), predelih za fizično rekreacijo in toliko neizrabljenih zelenih površin, da je mogoče govoriti o ravnotežju med naseljem in nedotaknjeno naravo.

Savlje, Kleče in Stožice so tisti deli tega območja, ki so zaradi odmaknjenosti od glavnih vpadnic najbolj ohranili elemente ruralnega. Območje Savelj lahko glede na fizični videz razde-

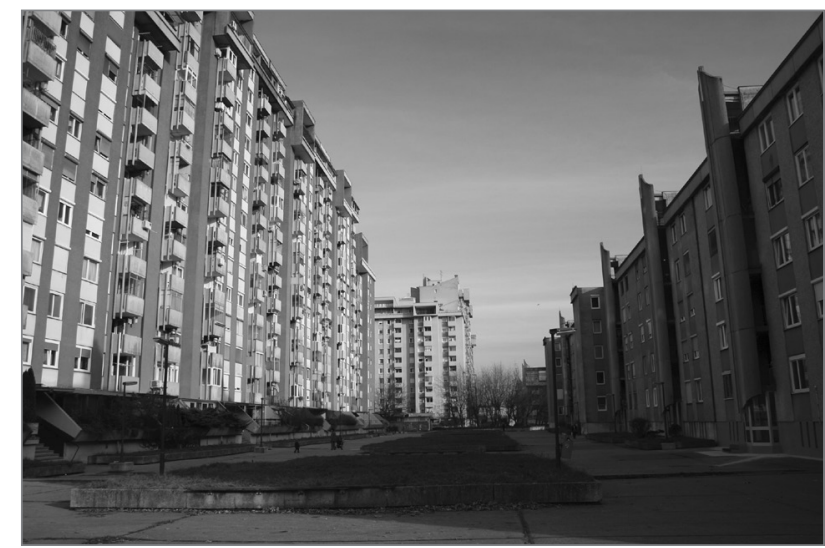

Slika 3: Bratovševa ploščad (foto: Barbara Turk Niskač)

limo na dva dela. Novi del se nahaja med železniško progo in Saveljsko cesto. Zanj je značilna povojna gradnja individualnih hiš, ki je povzročila nastanek novih ulic za glavno cesto. Drugi del Savelj pomeni stari vaški del naselja, ki ga zaznamuje obcestna vaška arhitektura z nekaterimi še danes delujočimi kmetijami. Poselitev v Klečah je strnjena ob glavni cesti in se ni širila v prostor $\mathrm{z}$ novimi ulicami. Elemente ruralnega lahko najdemo tudi v obstoju hišnih imen, Kmečki strojni skupnosti Savlje Kleče (strojna kmetijska zadruga za Savlje in Kleče je bila ustanovljena leta 1907) in Kulturno prosvetnem društvu Savlje Kleče, ki skrbi za vsakoletno organizacijo folklorne prireditve štehvanja. Ježica in Mala vas sta od vseh nekdanjih vasi najbolj urbanizirani oziroma sta najmanj ohranili vaško podobo. $\mathrm{Na}$ nekdanji vasi spominjajo nekatere še ohranjene stare hiše, na Ježici tudi kakšen kozolec in kmetija. Precej bolj se je na Ježici in v Mali vasi uveljavila gradnja individualnih hiš $\mathrm{z}$ vrtom, ki se nahajajo zlasti med Dunajkko cesto in Savo. Po drugi strani pa Stožice v jedru še naprej ohranjajo značilnost obcestne vaške poselitve s še delujočimi kmetijami.

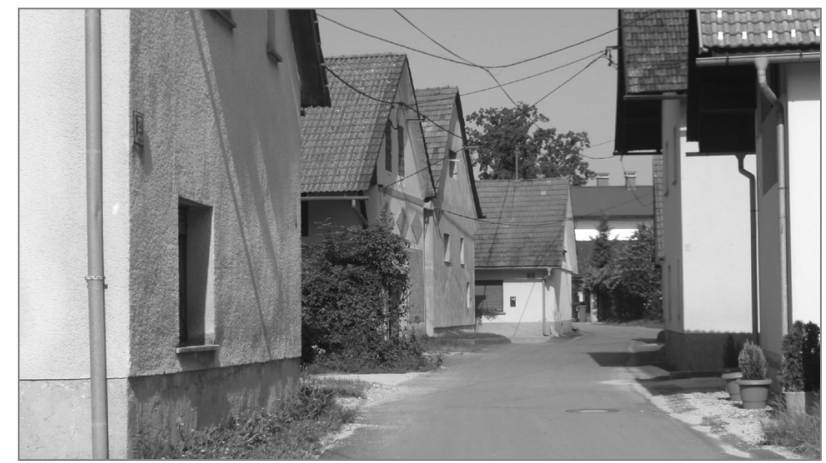

Slika 4: Stari del Savelj (foto: Saša Starec)

\section{Rezultati}

Danes je dojemanje obravnavanega prostora s strani njegovih prebivalcev večplastno, kar je razvidno iz vsebine pogovorov v naši raziskavi. Večina sogovornikov, tako v BS 7 kot v Klečah, Savljah in Stožicah, namreč območje BS 7 zaznava kot mestni 
prostor oziroma mesto. Mesto se za prebivalce Stožic začne onkraj obvoznice. Tudi območju BS 7 je zanje mesto, kajti visoke stolpnice so tisti fizični dejavnik, ki označuje mestni prostor, ne pa podeželja. Meja med mestom in podeželjem je za prebivalce Kleč in Savelj že območje BS 7. Nekateri pa menijo, da tudi BS 7 še ni pravo mesto, temveč predmestje oziroma obrobje. Zanimivo je, da gre pri tem za sogovornike, ki ne živijo v blokovskem naselju, temveč v okoliških hišah, ki obdajajo BS 7. Zanje se mesto začne z Bežigradom, oziroma po besedah mlajšega sogovornika: »Mesto se začne $\mathrm{z}$ infrastrukturo pri Bavarskem dvoru, tam so kino, bolj trgovine, tu ni nobene infrastrukture.« Dejstvo, da v BS 7 na ulicah ni veliko ljudi, da ni večjega števila trgovin ter je v splošnem vse bolj umirjeno in območje deluje predvsem kot spalno naselje, pri sogovorniku ustvarja vtis, da je ta prostor predmestje. $S$ sovrstniki se sogovornik druži v centru mesta in tudi njegove prostočasne aktivnosti niso vezane na proučevani prostor. Predmestni značaj tega območja tako izhaja iz primerjave z Bežigradom in s središčem mesta, ki z videzom in infrastrukturo v očeh sogovornikov vzpostavlja podobo mesta. To potrjuje, da gibanje $\mathrm{v}$ prostoru in umešcenost socialnih mrež vplivata na odnos do prostora. Ker pretežni del vsakodnevnih aktivnosti in družabno življenje potekata v središču mesta in je potrebno neprestano gibanje navznoter proti središču, se zdi tisto, kar je na obrobju, predmestje. Če je velik del posameznikovega življenja vezan na širši urbanizirani prostor BS 7 , če središče mesta ni prostor, $\mathrm{v}$ katerem poteka posameznikovo življenje, in zato ne prihaja do neprestanega gibanja proti njemu, pa prostor BS 7 še vedno pomeni mesto. Zato je za sogovornico, ki se $s$ prijatelji druži večinoma na območju BS 7, veliko manj pa v središču mesta, BS 7 še vedno mesto. Lahko rečemo, da sogovornica $\mathrm{v}$ konceptualizacijo ločnice med mestom in podeželjem vnaša izkušnjo prostora BS 7. Če namreč domnevamo, da sta obnašanje in prostor odvisna drug od drugega, nam okolje »nalaga določene omejitve pri gibanju, naše predstave pa se oblikujejo z našo zmožnostjo gibanja (Ardener, 1997: 2).

Naši sogovorniki se strinjajo glede tega, da je območje BS 7 urbano območje. Vprašljivo pa je, ali so Savlje že podeželje ali so še mesto. Za ljudi, ki so se rodili na »obrobju « (na območju Kleč, Savelj, Stožic in Ježice), in za tiste, ki so tukaj živeli, ko je bila razlika med vaškimi naselji in mestom izrazitejša, je to nedvomno prostor, ki pripada podeželju. Med starejšsimi generacijami, vajenimi nekdaj ostrejše delitve tega območja na urbano in ruralno, zlasti pa pri tistih, ki se še danes ukvarjajo $s$ kmetijstvom, je mogoče zaznati negativen odnos do mesta. To se z večnadstropnimi novogradnjami širi in požira vmesni pas nekdaj obdelovalnih površin, ki bile fizična ločnica med različnima prostoroma. Pri »domačinih « lahko opazimo velik pomen, ki ga ljudje pripisujejo temu, da niso del mesta. V nasprotju s Saveljčani, ki menijo, da so Savlje podeželje, in nekako zviška gledajo na stanovanjske bloke BS 7 , gospa iz
Savelj, ki vsak dan prodaja zelenjavo na Bratovševi ploščadi ter je v vsakodnevni interakciji s tem prostorom in odvisna od njega, Savlje in tudi BS 7 pojmuje kot predmestje. Pravi, da so »Savlje podeželje, se meša mesto. Tudi v Savljah so hiše že bolj mestne, vsak hoče imeti ne vem kakšno hišo. Klele je vse še zelo /.../ ni še podeželsko, je bolj predmestje.« Zlasti je zanimiva zaznava prostora pri tistih, ki so se z mladimi družinami priselili na »obrobje «. Pri njih je zaznava prostora ali kot mesta ali kot podeželja najbolj kompleksna in odvisna od vidika, s katerega gledajo na prostor. Njihova naselitev v hišo na obrobju je povezana s kakovostnim prostorom bivanja - tukaj je mir, ki ga po njihovem prinaša odmaknjenost od glavnih cest. Tu je tudi narava, kar naj bi bilo dobro za odraščanje otrok. Za sogovornico iz Kleč so zato Kleče bolj podeželske od Savelj, saj so odmaknjene od hrupa glavne ceste. Poleg tega pa so tu kmetije, kar ljudje pogosto povezujejo z odmaknjenostjo od mesta. Prostor je za mlade priseljence glede na zunanje označevalce bolj podeželje, vendar je hkrati še vedno mesto. Občutek mesta je vezan na bližino mestnega središča in s tem »urbanih « vsebin, ki so tako blizu, kot tudi na povezanost z mestom, ki jo pomenijo šola, služba, prosti čas, druženje, prijatelji. Tako nam je sogovornica v Klečah, ki se je iz BS 7 tja priselila v novozgrajene vrstne hiše, povedala, da je to območje zanjo tako mesto kot podeželje, po drugi strani pa je BS 7 že »čisto « mesto. Tisto, zaradi česar so Kleče v njeni zaznavi prostora podeželje, sta odmaknjenost naselja od hrupa in bližina narave, po drugi strani pa je območje del mesta zato, ker je še dovolj blizu središču mesta. Po njenem prepričanju so njeni otroci mestni otroci, saj hodijo v mestno šolo Danile Kumar (na območju BS 7), svoj prosti čas pa preživljajo na podeželju.

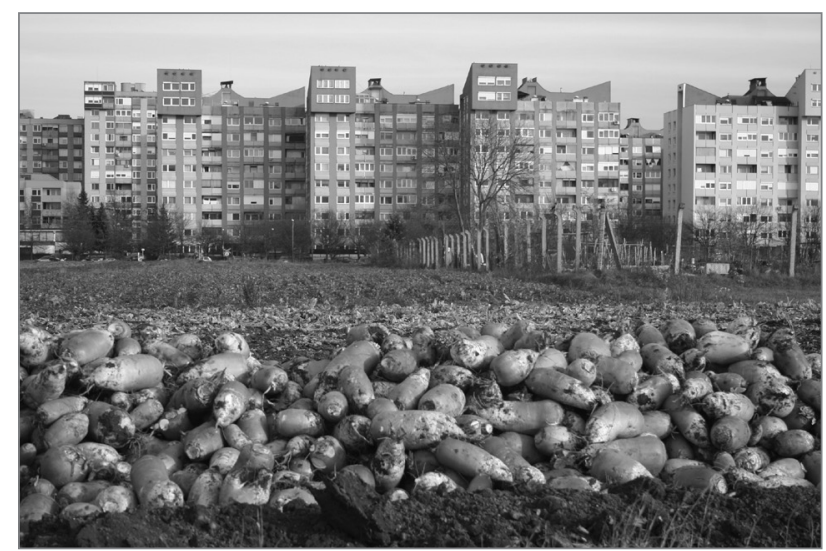

Slika 5: Pogled na Glinškovo ploščad (foto: Barbara Turk Niskač)

Med prebivalci BS 7 je mogoče zaznati različne odnose do prostora Savelj in Kleč. Nekateri so mnenja, da gre pri Savljah in Klečah že za podeželje, saj so tam kmetje in njive. Savlje vidijo kot vas predvsem v odnosu z območjem BS 7: »To je mesto, Savlje so pa že vas.« Za druge pa to območje ni podeželje oziroma je vse manj podeželje. Po njihovem prepričanju nekaj kmetij, ki so v Savljah, še ne pomeni, da gre za podeželje, 
poleg tega je teh kmetij vse manj. Podeželje je zanje območje, ki je bolj odmaknjeno od mesta, ki je drugačno in pomeni drugačen svet od mestnega. Za nekatere je to območje mesto zaradi mestnega avtobusa. Za druge to ni pravo podeželje, ker je mešanica urbanih in ruralnih elementov prevelika, da bi lahko vzdržala idejno podobo podeželja. Podeželje se tako za dva sogovornika iz BS 7 začne šele pri Gameljnah, kjer je po njunem mnenju že drugo območje, arhitektura, kultura, bolj čisto ozračje, več neurejenih gozdov, zaraščenost.

\section{Razprava}

Rezultati raziskave so pokazali, da imajo prebivalci Savelj, Kleč in Stožic veliko močnejšo percepcijo meje med mestom in podeželjem. To bi lahko izhajalo iz tega, da so njihove življenjske prakse takšne, da natančneje ločujejo med urbanim in ruralnim prostorom.

\subsection{Prebivalci vasi in pogled na mesto}

Predstava sogovornikov o prostoru izhaja iz konkretne izkušnja prostora (organizacija in udeležba na štehvanju, imaš kmetijo - si kmet, zjutraj se zbudiš ob petju petelina, razgled imaš na njivo in sosedov hlev, sodeluješ v strojni zadrugi, tvoj najboljši prijatelj je kmet iz sosednje hiše itd.). Tako so za najstnico iz Kleč, katere starši imajo kmetijo, v neposredni bližini katere je še več delujočih kmetij, Kleče veliko bolj podeželske od Savelj, v katerih se že začnejo mešati kmetije in naselje individualnih hiš. Pri starejših »domačinih « bi k takšni izkušnji prostora lahko dodali tudi identifikacijo z vaškim izvorom teh naselij in s tem povezan občutek drugačnosti glede na mestni način življenja. S tem pa je povezan tudi odklonilen odnos do mestnega prostora, ki pomeni svet, drugačen od tistega, $\mathrm{v}$ katerem bivajo. Ta konkretna izkušnja bivanja v prostoru, ki je odmaknjen od urbanega prostora mesta, je močnejša od razumske predstave podeželja, na podlagi katere prebivalci BS 7 razmišljajo o meji med mestom in podeželjem.

\subsection{Prebivalci BS 7 in njihov pogled na okoliške vasi}

Prebivalci BS 7 v glavnem izhajajo iz izkušnje bivanja v mestnem prostoru in vidijo v podeželju zrcalno sliko mesta - podeželje je prostor narave in miru, kmetij in njiv. Zaradi predstave tega, kaj naj bi podeželje bilo, med sogovorniki iz BS $7 \mathrm{ni}$ tako nedvoumne opredelitve, da so Savlje že podeželje. Poleg tega je njihov pogled usmerjen proti centru in ne na območja, ki so še bolj oddaljena od središča kot sami. Če se navežemo na Malcolma Chapmana (1992), so kulturni procesi v odnosu med centrom in periferijo povezani z identiteto, $\mathrm{z}$ biti nekomu podoben ali biti drugačen od njega. Po njegovem lahko »pe- riferijo obravnavamo kot premikajočo se ločnico, ki se lahko uresničuje kjer koli med centrom in koncem. Takšna vmesna periferija si želi biti ,kot' center, oddaljen od samega sebe, in ,ne kot' nekaj, kar je še bolj periferno kot ona sama « (prav tam: 96). Če domnevamo, da pomeni center izrazito urbano območje, so na periferiji ločnice zabrisane in tu eno območje prehaja v drugo. James Fernandez (2000) predvideva, da so tam, kjer so ločnice, tudi centri in periferije. Predvideva, da centri potrebujejo periferijo ter da izkušnja bivanja na periferiji oblikuje občutek identitete in način razmišljanja. Posameznik naj bi lahko prešel iz centra na periferijo in obratno, ne da bi prestopil ločnico. Čeprav so meje in ločnice do neke mere naravne ali geografske, so po njegovem predvsem mentalne in materialne.

\subsection{Mesto, podeželje in »vmesni« prostori bivanja}

Mejnost tega obrobnega območja in prehajanje mestnih in ruralnih elementov pomeni nekaterim sogovornikom iz BS 7 težavo pri natančnem opredeljevanju prostora ali za mestni ali za podeželski prostor. $\mathrm{V}$ njihovi predstavi je to obrobje $» v m e s n i \ll$ svet. To je bilo mogoče jasno opaziti pri fantu, ki sedaj študira v Ljubljani in prihaja iz podeželskega okolja. Kot pravi, »se tukaj nahaja neka čudna mešanica med urbanim in kmetijami, čudna kombinacija, ki ne gre skupaj«. Lahko torej rečemo, da je njegova izkušnja podeželja drugačna od izkušnje ljudi iz Savelj, Kleč in Stožic, ki po svoji opredelitvi živijo na podeželju.

Da se naše predstave lahko spreminjajo $\mathrm{v}$ skladu z našimi izkušnjami bivanja v prostoru, potrjuje primer fanta iz Črnuč, ki sedaj živi v BS 7. Zanj so bile Črnuče, ko je še živel tam, vedno del Ljubljane, sedaj pa jih dojema bolj kot predmestje. Drug dejavnik, ki lahko začne spreminjati zaznavo prostora, so novogradnje. Tako nam je sogovornica iz Stožic dejala, da so Stožice še naprej ostale podežllje tudi zato, ker se mesto na to območje ni širilo z novogradnjami. Tomačevo, ki je tudi vaškega izvora, postaja po njeni interpretaciji zaradi novogradenj vse bolj mesto, $s$ tem pa izgublja značaj podeželskega naselja. Da pozidava območja krči podeželje (» podeželje izginja na račun gradnje hiš «), je menila tudi sogovornica iz Kamnika, ki ob sobotah na Bratovševi ploščadi prodaja zelenjavo.

Čeprav se večina sogovornikov strinja, da je BS 7 mestni prostor, podoba mesta v zaznavi ljudi vendarle ni enovita. So predeli mesta, ki so »bolj《 mesto, ki so dejansko mesto (simbolizirajo mesto), in so predeli mesta, ki so sicer deli mesta, niso pa » pravo « mesto. Tako se mesto za prebivalce Savelj začne že pri BS 7 oziroma pri mostu čez železnico, za prebivalce Stožic pa na drugi strani obvoznice. Območje BS 7 pri tem zaradi 
blokovske gradnje pomeni izrastek mesta, ki sega onkraj obvoznice. Za večino sogovornikov pa je »pravo « mesto območje, ki se začne pri osrednjem stadionu oziroma Astri in se razteza proti centru. Za sogovornico, ki se je priselila v Savlje, je BS 7 urban prostor, ni pa še »mesto «. »Pravo « mesto je center mesta. Podobno razmišlja tudi gospa, ki na Bratovševi ploščadi prodaja zelenjavo: »Mesto se širi, tu deluje kot predmestje. Ritem je tu drugačen kot čisto v mestu, manj je inštitucij kot v mestu, banka, pošta, tu so, a bolj na redko. V mestu so vse pomembnejše stvari. Ne bi rekla, da je ravno tukaj mesto.« BS 7 je v nasprotju z območjem » pravega « mesta (center mesta), ki ga simbolizirajo hrup, promet, pozidava, gneča ljudi, javne ustanove in podobno, drugačen: je miren, odmaknjen, blizu narave. Večina ljudi ceni zeleno okolico, bližino centra, avtobusno povezavo in dobro infrastrukturo ter se zaradi teh pozitivnih značilnosti ne bi selila bliže središču mesta. Pravijo, da je » vse ravno prav blizu in ravno prav daleč «. V bivanju na obrobju vidijo korist, saj so blizu elementom, ki jih povezujejo s podeželjem, hkrati pa so jim blizu vse funkcije, zaradi katerih lahko mirno rečejo, da so del mestnega prostora. Dejansko se zdi, da se zaznava ločnice med mestom in podeželjem v predstavi sogovornikov premika glede na oddaljenost od mestnega središča. Za prebivalce Kleč so na primer te bolj podeželske od Savelj. Za Saveljčane se mesto začne z blokovskim naseljem BS 7, za prebivalce Stožic se mesto začne čez obvoznico. Zaznava mestnega prostora se tako vedno navezuje na pogled proti središč mesta, proti pravemu mestu, medtem ko je pogled na podeželje vedno usmerjen stran od središča. Chapman (1992: 95 in 96) odnose med centrom in periferijo razlaga tako:

[V]sak del bliže centru lahko deluje kot center za dele, ki so bolj oddaljeni; vsak del bliže periferiji lahko deluje kot periferija za dele bliže centru. Če stojiš v centru in gledaš ven, je vse periferija. Če pa z obrobja gledaš proti notranjosti, je vse center. Seveda gre tu za ekstremne pogoje. Za večino ljudi je center v eni smeri in periferija v drugi. Proces pa ni samo prostorski in geografski; dogaja se tudi skozi družbene strukture; mesto lahko pomeni center za vas, predmestje srednjega sloja predmestju delavskega razreda /.../ Gre za splošne izjave, ni pa vedno jasno, kje sta center in periferija.

$\mathrm{V}$ tej igri oddaljenosti in semiotike prostora je najzanimivejši položaj Stožic. Ker so takoj za obvoznico in pred BS 7 in ker jih Dunajska cesta tudi ločuje od neposrednega stika z BS 7,v gledanju proti središču ne zaznajo BS 7 kot fizičnega označevalca, ki bi napovedoval ločnico med mestom in podeželjem. Sogovornike iz Stožic je bilo vedno treba povprašati, kaj pa BS 7? Je to že podeželje ali je to mesto? Iz njihovih odgovorov se je pokazalo, da območje BS 7 zaradi blokovske gradnje sicer res dojemajo kot mestni prostor, vendar je zanje mnogo večja ločnica obvoznica in vsa zgoščena gradnja stolpnic, ki jih gledajo pred seboj.

\subsection{Starost in dojemanje območja BS 7}

Dojemanje prostora pa ni pogojeno samo s prostorom, v katerem živimo, ampak je povezano tudi s starostjo. $S$ starostjo so povezane različne osebne izkušnje in tudi različni interesi posameznikov, oboje pa vpliva na vrednostni sistem posameznika, prek katerega ta doživlja prostor. Ločnica med mestom in podeželjem je najmanj dvoumna pri starejših prebivalcih. Za starejše, ki bivajo v BS 7, je prostor stanovanjske soseske del mesta. Za starejše, ki bivajo v Savljah in Stožicah, je njihov prostor podeželje. Blokovsko naselje BS 7 je za vse starejše sogovornike mesto, medtem ko so zanje okoliški predeli - Savlje, Kleče in Stožice - podeželje. Vzroke za tako jasno delitev prostora lahko pripišemo izkušnji prostora, ki se je oblikovala že pred tridesetimi, štiridesetimi leti (pred izgradnjo BS 7), ko so bile razlike med urbanim in podeželskim na tem območju veliko jasnejše. To so ljudje, pri katerih sta mesto - blokovska gradnja, beton, množica - in podeželje - kmetije, njive - v jasni opoziciji. Pri starejših sogovornikih, ki izhajajo s podeželja (glede na njihovo samoopredelitev), je mogoče zaznati izrazito negativen odnos do mestnih, urbaniziranih površin, ki so se razširile v »njihovo « podeželsko okolje. Jasna opozicija med mestom in podeželjem se pri starejših sogovornikih kaže tudi v povezavi z njihovimi prostori srečevanja s sovrstniki. Za sogovornike, ki živijo v BS 7, je značilno, da poteka njihovo druženje pretežno v središču mesta. To je povezano z uporabo mestnega avtobusa in večjo navezanostjo na mestni prostor. Za starejše sogovornike iz Savelj in Stožic pa je značilno, da so bolj navezani na lokalno okolje. Pri starejših prebivalcih tega območja ni bilo mogoče opaziti možnosti, ki bi dopuščala prehajanje glede na okoliščine, kot je to značilno za mlade »priseljene « družine, ki so si izbrale bivanje na »obrobju « zato, da lahko zadostijo občutku, da bivajo na podeželju, vendar so hkrati še vedno del mesta. Pri teh skupinah je predstava meje med mestom in podeželjem najmanj statična. $V$ splošnem lahko pri skupini sogovornikov med 20. in 55. letom starosti zaznamo najmanj konsenza glede postavljanja meje med mestom in podeželjem, pri čemer se ta neenotnost razmejitve nanaša na območje Savelj. Zaradi obstoja kmetij ter lege tega območja ob odprtem prostoru kmetijskih in travnatih površin je za nekatere to območje že podeželje, za druge pa je zaradi obstoja mestnega avtobusa in tesne navezave na mesto še vedno del mesta. Pri tem je treba opozoriti na to, da velja ta neenotnost postavljanja meje predvsem za tiste, ki bivajo na območju BS 7 in manj za tiste, ki prihajajo iz Kleč ali Savelj. Za slednje je območje Savelj in Kleč pogosteje nedvomno podeželje. To se je pokazalo v pogovoru s skupino sogovornikov, starih med 30 in 35 let, ki se med seboj poznajo in prihajajo tako iz Savelj in Kleč kot iz BS 7. Ti sogovorniki so jasno definirali mejo med podeželjem in mestom, menili so, da je »meja med mestom in podeželjem na mostu «, torej železnica, pri kateri se začnejo Savlje. V širšem kontekstu so nam pojasnili, da je, »če vprašaš 
koga iz Savelj ali Kleč, /.../ to podeželje, če pa vprašaš ljudi iz blokov, so iz mesta «. Mladi med 15. in 20. letom starosti so območje BS 7 presenetljivo enotno opredelili kot predmestje oziroma kot prostor, ki še ni pravo mesto (pomanjkanje urbanih elementov), ni pa niti podeželje. V glavnem pa se vsi strinjajo o tem, da je območje, ki se razprostira za BS 7 (Savlje, Kleče), že podeželje.

\section{Glavne ugotovitve in sklep}

Če zelo na splošno povzamemo besede sogovornikov, lahko sklepamo, da večina sogovornikov območje BS 7 dojema kot mestni prostor, območje Savelj, Kleč in Stožic pa kot podeželje. Značilnosti mestnega in podeželskega okolja, na podlagi katerega konstruirajo ločnico med mestom in podeželjem, opredeljujejo:

- Podeželje je po njihovem mnenju prostor, v katerem so njive, kmetije, traktorji, krave, narava, mir, redkejša poseljenost, boljši zrak, drugačni običaji in navade kot $\mathrm{v}$ mestu (npr. štehvanje). Drugačna je tudi komunikacija, saj se na podeželju bolj poznajo med seboj, vsi vedo vse o vseh. Na drugi strani pa v bloku ne poznajo vsi vseh.

- Mesto je po njihovem prostor, v katerem so mestna infrastruktura, večja gostota prebivalstva, malo zelenega prostora, promet, hrup, gneča in stolpnice. Te značilnosti tvorijo najpopolnejšo predstavo tega, kar je podeželje in kar je mesto.

Kako se te idealne predstave povezujejo s konkretnim stanjem na območju četrtne skupnosti Posavje, je stvar posameznikove zaznave prostora. Bolj ko je okolje blizu popolni predstavi, laže je sogovorniku umestiti prostor na podeželje ali v mesto. Prebivalcev BS 7 območje Savelj kot območje v nasprotni strani od centra mesta niti ne zanima, razen kot območje rekreacije, občasnih sprehodov in morda nakupa poljedelskih izdelkov. Tudi njihove predstave o Savljah so pogojene z mestno izkušnjo prostora, ločnico med urbanim in ruralnim pa si predstavljajo predvsem razumsko. Tako je tudi njihova percepcija Savelj pogojena bolj z razumsko predstavo in ne toliko $s$ praktično izkušnjo ruralnosti. Ločnica med mestom in podeželjem zato pri prebivalcih BS 7 bolj variira. Nasprotno se zdi, da imajo prebivalci Savelj močnejšo percepcijo razmejitve med mestom in podeželjem, med urbanim in ruralnim prostorom. Lahko bi dejali, da njihova predstava o ruralnem okolju izhaja iz konkretnejše izkušnje ruralnega okolja. Kljub temu posplošenemu seštevku interpretacij pa je treba vendarle nedvoumno dodati, da je določanje jasnih meja med urbanim in ruralnim problematično, saj ljudje tega prostora ne dojemajo črno-belo. Vsak posameznik si ustvari svoje videnje in vrednotenje okolja, pogosto na nezavedni ravni. Najnatančneje določeno mejo med urbanim in ruralnim podala skupina tridesetletnikov iz Savelj in Kleč, ki jo je brez oklevanja postavila na bližnji most čez železnico. Ker je pogovor potekal le nekaj deset metrov stran od omenjene lokacije, se zdi, da so sogovorniki mejo laže določili, ker je bila fizično blizu. Po drugi strani prebivalci BS 7 sicer ločijo med mestom in podežljem, vendar ne postavljajo jasne fizične meje.

$\mathrm{Na}$ podlagi opravljene terenske raziskave lahko glede meje med podeželjem in mestom sklenemo, da je v času, v katerem živimo, jasne, enopomenske meje med mestom in podeželjem težko določiti. Tudi zato, ker se ruši povezava med elementi, ki bi jih porazdelili v dvojici mesto-podeželje, urbano-ruralno. To ljudi zmede, saj morajo na novo definirati značilnosti tako urbanega kot ruralnega. »Savlje so še vedno mesto, je par kmetov, /.../ imajo polno hlevov, kar ni ravno indikator mesta, je pa mestni avtobus. « Iz navedenega lahko vidimo, v kolikšni meri se pravzaprav urbano prepleta z ruralnim. Danes pred nami nastajajo vmesne kategorije urbaniziranega podeželja (katerega sinonim je mir, bivanje v naravi) in ruralnega mesta (katerega sinonim so kmetije, ki skrbijo za samooskrbo mesta $s$ svežimi živili), pri čemer je ruralno mesto v glavnem na obrobju mesta. Ti »vmesni prostori « niso urbano mesto, katerega sinonim bi bilo poslovno, trgovsko in kulturno središce mesta, javni prostor, koncentracija ljudi in prometa. Prav tako niso podeželje, na katerem bi živeli kmetje, obdani s kmetijskimi površinami in $\mathrm{z}$ nedotaknjeno naravo. $\mathrm{Ti} \gg$ vmesni prostori «, ki so med podeželjem in mestom, so dvakratno obrobje. Z vidika » pravega « podeželja so obrobje podeželja, pravzaprav niti niso več pravo podeželje, ker je preveč vplivov mestnega načina življenja. $Z$ vidika »pravega « mesta so obrobje mesta, njegova skrajna meja, skoraj že podeželje. Največjo težavo pri razumevanju vprašanja, kje se konča mesto in začne podeželje, povzroča sodoben način bivanja, pri katerem postajajo fizične meje vse manj izrazite in nedvoumne. Urbanizacija prostora je močno omajala nekoč jasno mejo med mestom in podeželjem. Na to opozarja Thomas Sieverts (2003), ki meni, da je danes romantične predstave o tem, da se za koncem mesta skriva popolnoma drugačen svet podeželja, konec. Opravka naj bi imeli z urbanizirano urbano-ruralno pokrajino, $\mathrm{v}$ kateri ni ostre meje med mestom in podeželjem, ampak gre za mešanico različnih struktur, ki prehajajo druga v drugo. Nastaja nov tip poselitve prostora, ki ga Sieverts imenuje Zwischenstadt; to je pozidano območje, ki se nahaja vmes med starimi zgodovinskimi mestnimi jedri in odprtim podeželjem in ima tako značilnosti urbanega kot ruralnega. Ni niti mesto niti pokrajina - »je območje bivanja, ki ga lahko, glede na interes in perspektivo tistega, ki interpretira, razumemo ali kot mesto ali kot podeželje (prav tam: 3). Takšno območje je nastalo kot posledica novih družbeno-ekonomskih razmer, $\mathrm{v}$ katerih je postalo pomembno, kje se živi - pri tem pa je kakovost/narava bivanjskega prostora veliko pomembnejša od tega, da se dom nahaja blizu mestne infrastrukture/delovnega mesta. Ljudje se selijo iz mesta, ker so bivanjske razmere ugodnejše; so blizu 
narave, imajo več zasebnosti, mir, ni hrupa ne prometa, hkrati pa imajo zaradi prometne povezave občutek, da so blizu mesta.

Če želimo problematiko na lokalni ravni razumeti prek preproste in stereotipne razlike med urbanim in ruralnim, naletimo na težave, saj so percepcije večplastne in se oblikujejo kot odziv na lokalna vprašanja, povezana s prostorom. Če je bilo še pred nekaj desetletji bivanje na podeželju zaznamovano z bivanjem na kmetiji ali med kmetijami, je danes predstava bivanja na podeželju povezana zlasti z bivanjem v naravnem okolju, stran od hrupa in prometa, ki sta za večino ljudi temeljni izkustveni lastnosti mesta. Če je bilo obrobje še do pred nekaj desetletji območje kmetij in obdelanih kmetijskih površin, postaja danes vse bolj iskano območje naselitve tistih mestnih ljudi, ki si želijo bivati v naravi, vendar hkrati blizu mesta. Neobstoj te nedvoumne razlike med ruralnim in urbanim kot različnima načinoma življenja bo vse bolj povečeval območje »vmesnih prostorov « ter zabrisoval jasno ločnico med mestom in podeželjem. Ta ločnica bo zato vse bolj stvar mentalne predstave posameznikov in manj zunanjih fizičnih kazalcev. Ta spoznanja potrjuje tudi Walter Zenner (2006), ki meni, da so spremembe, do katerih je prišlo v zadnji polovici stoletja, pripeljale do tega, da je razlika oziroma meja med urbanim in ruralnim vse manj opazna. Čeprav se po njegovem mnenju meje zabrisujejo, ljudje v svoji percepciji prostora še vedno zaznavajo razliko med urbanim in ruralnim.

\section{Barbara Turk Niskač}

Univerza v Ljubljani, Filozofska fakulteta, Oddelek za etnologijo in

kulturno antropologijo, Ljubljana, Slovenija

E-pošta: turkowa@gmail.com

\section{Simona Klaus}

Univerza v Ljubljani, Filozofska fakulteta, Oddelek za etnologijo in kulturno antropologijo, Ljubljana, Slovenija

E-pošta: simona.klaus@gmail.com

Saša Starec

Ljubljana, Slovenija

E-pošta: sasa.starec@gmail.com

\section{Viri in literatura}

Ardener, S. (1997): Ground rules and social maps for women: An introduction. V: Ardener, S. (ur.): Women and space: Ground rules and social maps, str. 1-30. Oxford, Berg.

Bender, B. (2001): Introduction. V: Bender, B., in Winer, M. (ur.): Contested landscapes: Movement, exile and place, str. 1-18. Oxford, Berg.

Chapman, M. (1992): The Celts: The construction of a myth. London, The MacMillan Press.

Fernandez, W. J. (2000): Peripheral wisdom. V: Cohen, P. A. (ur.): Signifying identities: Anthropological perspectives on boundaries and contested values, str. 117-144. London, Routledge.
Geodetska uprava Republike Slovenije (2010): Zemljevid Ljubljane. Ljubljana.

Giarchi, G. G. (2006): Older people "on the edge" in the countrysides of Europe. Social policy administration, 40(6), str. 705-721.

Harris, M. (1956): Town and country in Brazil. New York, Columbia University press.

Madanipour, A. (1996): Design of urban space: An inquiry into sociospatial process. Chichester, Wiley.

Low, S. (1999): Theorizing the city: the new urban anthropology reader. New Brunswick, Rutgers University Press.

Mihelič, B. (1983): Urbanistični razvoj Ljubljane. Ljubljana, Znanstveni inštitut Filozofske fakultete, Partizanska knjiga.

Muršič, R. (2006): Nova paradigma antropologije prostora: Prostorjenje in človeška tvornost. Glasnik slovenskega etnološkega društva, 46 (3 in 4), str. 48-55.

Mušič, V. B. (1960): O stanovanjskih skupnostih kot urbanističnem elementu. Ljubljana, Urbanistični inštitut Ljudske Republike Slovenije.

Okrajni zavod za Urbanizem Ljubljana (1961): Vplivno območje mesta Ljubljane. Ljubljana.

Pajsar, B., in Židov, N. (1991): Etnološka topografija slovenskega etničnega ozemlja: 20. stoletje. Občina Ljubljana Bežigrad. Ljubljana, Znanstveni inštitut Filozofske fakultete.

Scott, A., Gilbert, A., in Gelan, A. (2007): The urban-rural divide: Myth or reality? Dostopno na: http://www.macaulay.ac.uk/economics/ research/SERPpb2.pdf (sneto 13. 8. 2009).

Sieverts, T. (2003): Cities without cities: An interpretation of the Zwischenstadt. London, Spon Press.

Zenner, W. (2002): Beyond urban and rural: Communitues in the 21 st century. V: Gmelch, G., in Walter, Z. (ur.): Urban life: Readings in the anthropology of the city, str. 53-60. Prospect Heights, Waveland Press. 